\title{
The Impact of Social Media on the Performance of Microfinance Institutions in Developing Countries: A Quantitative Approach
}

Daowd, A., Kamal, M. M., Eldabi, T., Hasan, RUAA., Missi, F. \& Dey, B. L.

Author post-print (accepted) deposited by Coventry University's Repository

Original citation \& hyperlink:

Daowd, A, Kamal, MM, Eldabi, T, Hasan, RUAA, Missi, F \& Dey, BL 2020, 'The Impact of Social Media on the Performance of Microfinance Institutions in Developing Countries: A Quantitative Approach', Information Technology and People, vol. (In-press), pp. (In-press). https://dx.doi.org/10.1108/ITP-03-2018-0135

DOI $\quad 10.1108 /$ ITP-03-2018-0135

ISSN $\quad 0959-3845$

Publisher: Emerald

Copyright $₫$ and Moral Rights are retained by the author(s) and/ or other copyright owners. A copy can be downloaded for personal non-commercial research or study, without prior permission or charge. This item cannot be reproduced or quoted extensively from without first obtaining permission in writing from the copyright holder(s). The content must not be changed in any way or sold commercially in any format or medium without the formal permission of the copyright holders.

This document is the author's post-print version, incorporating any revisions agreed during the peer-review process. Some differences between the published version and this version may remain and you are advised to consult the published version if you wish to cite from it. 


\title{
The Impact of Social Media on the Performance of Microfinance Institutions in Developing Countries: A Quantitative Approach
}

\begin{abstract}
Purpose - Over the last few decades, microfinance industry is argued to have played a constructive role in alleviating poverty level and providing the underprivileged with access to financial services. Statistics from the World Bank reveal that, currently, only $4 \%$ of the underprivileged have been served out of the 3 billion+ potential clients. Such results are due to several claims, particularly the operational and financial challenges faced by microfinance institutions (MFIs) in the constant flux inviting more attentions towards its performance. While explicit attention is given by many researchers towards mobile banking and information and communication technology (ICT) in improving the MFIs performance, the study on how social media, as a rapidly growing online phenomenon, can impact on the MFIs performance remains scarce. As such, this study aims to investigate this impact based on four dimensional performance indicators: efficiency, financial sustainability, portfolio quality, and outreach.
\end{abstract} Design/methodology/approach - A model is proposed and tested to ascertain the relationship between social media applications and organisational performance. In so doing, web-based questionnaires have been used to collect data from MFIs employees in developing countries. Results reveal a significant influence of the social media over the MFIs performance, offering valuable insights into both researchers and practitioners in the domain of microfinance, as well as social media - conforming that the adoption of social media as marketing, advertising and communication tools may significantly improve the MFIs performance.

Findings - The results demonstrate that there is a positive and significant impact of social media use within microfinance on the key indicators of MFIs. They also show that the highest impact of social media usage (SMU) within the microfinance is on the portfolio quality. In addition, it was found that marketing and advertising, communication, and sales and distribution are the main areas where social media is able to support while social networking websites are the most popular platforms employed in MFIs.

Originality/value - This study adds to the existing literature few theoretical and practical aspects. First, this study developed a model for assessing the value of social media as a new phenomenon within this type of organisation. Second, it offers microfinance sponsors, managers, and policy makers with a frame of reference to understand what social media platform can be deployed for each purpose. Third, with the identification of the main MFIs performance indicators, this research provided a reference of performance measurement guide for microfinance industry when assessing different technological employment.

Keywords - Microfinance, Microfinance Institution, Performance, Social Media, Information and Communication Technology. 
Paper Type - Research Paper

\section{Introduction}

Microfinance is related to offering a broad range of financial services to low-income households in order to help them set up their micro-enterprises (Charitonenko and Campion, 2003). Lack of reasonable credit track record and instability are usually the main reasons why most of the poor are not able to access the traditional financial services (Todaro and Smith, 2009). Despite its well documented benefits, microfinance industry in all developing countries suffers major difficulties that hinder its performance improvement (Nugroho et al., 2017). One of the major issues in this regard, is the high operation costs as it forces MFIs to pass on these costs to their clients, making it harder for the targeted population (Sabi, 2013). It was evident that the ultimate challenge of microfinance industry is the high operational cost that was translated into high interest rates, and imposed on the clients (Acha Ikechukwu, 2012; Morduch, 2000). According to a study carried out by UNDP (2003), microfinance banks charge between $30 \%-100 \%$ interest on loans while they pay $4.5 \%$ to $6 \%$ on savings, calling upon criticism from various quarters (Brau and Woller, 2004; Serrano-Cinca and Gutiérrez-Nieto, 2014).

Innovations in the area of information and communication technology have continued to revolutionise the banking industry. It is suggested that utilisation of ICT and mobile banking technologies, can potentially support MFIs in improving their performances (Augsburg et al., 2011; Diniz et al., 2008). ICT led initiatives such as mobile banking have proven to be effective in supporting MFIs within many developing countries such as India and Kenya (Ashraf et al., 2017; Mas and Radcliffe, 2011). However, such effectiveness is met by a number of constraints including among others are, regulatory environments, infrastructure, high skilled staff availability, financial resources, and others (Rozzani et al., 2013; Molina, 2013). In line with the latter, Al-Jabri and Sohail (2012) report that the delivery of financial services has experienced major changes during the past several years, with the banking industry across the globe increasingly becoming competitive.

Thus to improve its performance, MFIs need to employ technological tools that all stakeholders can access, understand, and afford. Numbers from Statista (2018) show that 8 out of 10 top Facebook's active users by nations are from developing countries and 9 out of 10 for WhatsApp (Statista, 2018). This numbers demonstrate that social media is accessible, understandable, and affordable by individuals within the context of MFIs' operations. With respect to its benefits, social media holds huge potentials for improving some aspects of the MFIs' operations, particularly in marketing and communication, leading to improved collaboration, brand loyalty, cost reduction, and revenues (Lyon and Montgomery, 2013; Edosomwan et al., 2011). Murugesan (2007) found that social media includes a multitude of sources of online information that are created, circulated and used by consumers to educate one another about products, services, and brands available in the marketplace. Similarly, Davison and Ou (2016) 
addressed the importance of social media as a channel for increasing customer satisfaction and for employees to engage in knowledge sharing. Social media platforms are source of horizontal and vertical flow of frequently updated information and knowledge. It has a clear identity and it gives the user multiple options of interaction (Siaka et al., 2014). Malekipirbazari and Aksakalli (2015) also emphasised on the importance of the mining of social media data for more accurate borrower risk attribution and thereby integration of social media into social lending.

Considering the work done specifically on the use of social media in the financial sector, we found that such use was addressed from different angles. For instance, while a study considered the predictive utility of evaluative textual information contained in online reviews (e.g. Tang et al., 2016), another assessed users' influence on social networks (e.g. Marcellis-Warin et al., 2017). On the other hand, Kaminski et al., (2018) explored the link between electronic word of mouth in the form of usergenerated content and through mass personal communication on the performance of crowdfunding campaigns. In addition, Hentschel et al., (2014) presented an exploratory analysis of cashtags in which they investigated how widespread cashtags are, what stock symbols are tweeted more often, and which users tweet about cashtags in general. A study also discussed utilising social media as a credit rating approach to determine companies' credibility level (Gül et al., 2018). Another study was conducted on SMU in the banking sector and recommended that managers of the banking sector in MENA countries should be conscious that their banks' performance could be enhanced (Mahboub, 2018).

Whilst there are several advocates voicing that social media improves the performance of MFIs in developing countries (e.g. Ashraf et al., 2009), there is still paucity of in-depth empirical works on investigating the value of social media with regard to MFIs' performance. In this paper, we seek to fill this gap by examining how and to what extent social media use can influence MFIs performance. In doing so, this research paper contributes to the current body of literature by providing a framework for assessing the value of social media within MFIs.

The remaining paper is structured as follows. Sections 2 reviews the previous studies by presenting technology implementations for MFIs; both ICT and Mobile banking technology implementations within MFIs in section 2.1 and 2.2. These are followed by presenting the value of social media on the firm performance in section 2.3 and the performance measurement indicators for MFIs. Research model and hypotheses development are presented in section 3, while discussion on the research methodology was illustrated in section 4 . Section 5 presents the results and findings followed by discussion in section 6. This study was concluded by research limitation and suggestion for further studies in this field.

\section{Related Work}




\subsection{Information and Communication Technologies Implementation in MFIs}

The role of information and communication technologies as a facilitator to development have been heralded in information systems and development economics scholarships (Pick et al., 2014; Dey et al., 2011; Abraham, 2007). Asongu et al., (2018a; b) conducted a study that examined how ICT influences openness to improve the conditions of doing business in sub-Saharan Africa. They found substantial evidence that ICT complements openness to improve conditions for entrepreneurship; the effects are contingent on the dynamics of openness, ICT and entrepreneurship. Weber et al., (2012) discussed the impact of ICT adoption on outreach capabilities of microfinance institutions considering both its breadth and depth. Their analysis revealed that ICT impact poverty outreach mediated through financial performance and loan portfolio improvements. On the other hand, Jawad et al., (2010) concluded that the implementation of ICT enables MFIs in developing and emerging countries to significantly improve their microfinance services whilst enhancing efficiency and customer relationship management. Moya Musa et al., (2012) assessed the impact of investment in ICT on performance and growth of microfinance institution in Uganda; they found that the ICT provides the opportunity to reduce transaction costs and improve coordination of various activities. Innovative ICT improves the efficiency of all inputs by improving the production processes and organisational structures of the firm. However, the cost of implementing ICT is considered as a major constraint of implementation, besides the existing high MFIs basic operations cost (Rozani et al., 2013; Kauffman and Riggins, 2012).

\subsection{Mobile Banking Usage in MFIs}

The experience of Kenya in using mobile banking in MFIs, is a benchmark in this context. First they launched a SMS-based money transfer system that allows individuals to deposit, send, and withdraw fund using their cell phone. Whilst in the Philippines the application of e-Money was implemented to carry out similar services from several outlets (Cellular-news, 2011). Moreover, Telenor Pakistan and Tameer Microfinance Bank have together created a "virtual organisation" to run their Easypaisa service (Davidson, 2011). Mobicash is also another Pakistani experience as a collaboration of Orascom Telecom and Waseela Microfinance Bank to be used by costumers to gain access for services of payment and M-wallet (Mobicash, 2012). Correspondingly, Hinson (2011) argued that if the traditional financial setting does not allow the poor to access the financial services like banking, the poor could be offered banking services through mobile technologies. Addressing social constraints remains a challenge in order for ICTs to contribute to development in developing countries.

Ashraf et al., (2017) explored how some rural centres in Bangladesh, influenced socio-economic development. They have found that the centres contributed to socio-economic development and this contribution was limited by social constraints, hindering the well-being of individuals and families. 
They concluded that addressing social constraints remains a challenge in order for ICTs to contribute to development in such developing country. Asongu et al., (2018a) assessed the correlations between mobile banking and inclusive development (poverty and inequality) in 93 developing countries. Their results show that at certain thresholds of the human development index (HDI), mobile banking is positively linked to inclusive development. Ala and Ngugi (2013) studied the influence of mobile banking on the growth of MFIs in Kenya; they concluded that access to financial services through mobile banking affects the growth of MFIs to a great extent.

\subsection{Social Media and Firm's Performance}

Social media is a unique resource with distinctive characteristics and has emerged as a promising alternative to conventional IT systems and communication innovations (Bughin, 2008; Mikalef and Pateli, 2017; Pateli and Mikalef, 2017). In words of McAfee (2006), the use of social media within companies, between companies, or with their partners and customers, is referred to as Enterprise 2.0. In line with the latter description on social media, it holds the potentials for companies to promote interfirm collaboration and developing closer connections with their customers, which is a fundamental objective for MFIs. In doing so, firms can increase revenue, reduce cost and improve efficiencies (Baird and Parasnis, 2011). For example, companies such as Dell reporting to have gained $£ 1.9$ million from sales and cost savings via Twitter (Davidson, 2009; Bulearca and Bulearca, 2010). The ease of use of different applications makes social media accessible to both inexperienced and technically orientated people (Lacho and Marinello 2010, p.128). It provides the organisations with a trustworthy platform to directly contact their clients - in line with this argument, literature confirms that individuals trust information they obtain through social media if it comes from brands' official profiles (Nisar and Whitehead, 2016).

Schaupp and Belanger (2013) developed a model to assess the value of social media for small businesses. Their investigation addressed the impact of social media on internal operations, marketing, customer service, and sales. Their model was grounded on the previous work of Zhu (2004); Zhu and Kraemer (2005); Gattiker and Goodhue (2006); Zhu et al., (2006); and Picoto et al., (2012). Furthermore, Tajvidi and Karami (2017) investigated the influence of social media on firm performance with mediating role of marketing capabilities in the UK, hotel industry. Their findings highlight that marketing capabilities positively and significantly mediate the association between social media use and firm performance. On the other hand, Pateli and Mikalef, (2017) claim that social media can also foster firm's innovation performance. Regardless of its importance and significant hype that surrounds social media, few research studies have examined their adoption as part of a business strategy - largely disregarding the adoption at the firm level i.e. not enough studies that looked at the impact of social media on MFIs performance, particularly in relation to meeting their social obligations. 


\subsection{Social Media in the Financial Sector}

Evidences from the literature support the claim that social media is a powerful tool to enhance organisation's activities. As the current research consider MFIs performance, this section is reviewing the studies focusing on social media impact within the financial sector. Among these, Tang et al., (2016) conducted a study in which they employed Automatic Text Analysis to investigate the predictive utility of evaluative textual information contained in online reviews. Based on a real-world dataset that matched electronic word of mouth (eWOM) with annual financial performance of 68 banks over an eight-year period, their study tested patterns of the bi-directional relations between eWOM indicators and banks' profitability over time. Their results showed that both star ratings and consumers' verbalised emotions in eWOM significantly predicted increases in firms' future profitability. Marcellis-Warin et al., (2017) assessed users' influence on social networks. They compared four different methods regarding tweets about financial conversations. Their results suggested that the number of followers is only one element of what is considered to be influential. They concluded that these methods of assessing influence on Twitter leverage the acquisition of preferential signals in a financial context. Kaminski et al., (2018) explored the link between electronic word of mouth in the form of user-generated content (online forum interactions on Kickstarter) and through mass personal communication (sharing information through Facebook) on the performance of crowdfunding campaigns. Their findings indicate a reverse causal effect. Social media activity follows a successful campaign, but does not affect the success probability of the campaign.

Wessel et al., (2016) assessed the effects of non-genuine social information on consumers' decisionmaking in the context of reward-based crowdfunding. Their results revealed that manipulated social information has a very short-term positive effect on backers' funding decision in a crowdfunding campaign. Additionally, they provided evidence that market conditions and campaign characteristics play an important role in shaping the likelihood of manipulations to occur on a crowdfunding platform. While Hentschel et al., (2014) presented an exploratory analysis of cashtags (a new way of sharing financial information taking place in social media) on Twitter, in which they investigated how widespread cashtags are, what stock symbols are tweeted more often, and which users tweet about cashtags in general. They concluded that cashtags, in particular in combination with other cashtags or hashtags, can be very useful for analysing financial information and provide new insights into stocks and companies.

Gül et al., (2018) proposed a multiple criteria credit rating approach to determine companies' credibility level utilising social media data as well as financial measures. Their results indicate that social media provides valuable information to determine companies' creditability. However, they concluded that 
credit ratings tend to decrease when social media data is considered. Mahboub (2018) published a study on SMU, specifically Facebook usage- in the banking sector of twelve different countries in the Middle East and North Africa (MENA) region. Their results indicated a positive significant impact of SMU on financial and non-financial performance of banks in MENA countries in terms of profitability, growth and environmental performance. Mahboub's (2018) research recommended that banking sector managers in MENA countries should be conscious that their banks' performance could be enhanced by developing capabilities and competences related to SMU and by having a strong intention to use these tools. However, the above presentation promotes the need for further empirical investigation of utilising social media for performance improvement within the financial sector as most of the studies focused more on social media use as a marketing tool.

\subsection{MFIs Performance Measurement Indicators}

Pakdel and Monroy (2010) described six characteristics of a good microfinance program such as small funds and short-term loans, short reposition (weekly or monthly). Also, Yaron (1994) discussed that, unlike for traditional banks; traditional indicators such as accounting profit do not measure MFIs performance well because they do not take into consideration the MFIs social goal and orientation. Yaron (1994) addressed two prime criteria for MFI success: (a) the level of outreach achieved with the targeted population, and (b) the degree of self-sustainability. The level of outreach can be determined as the type of clients MFIs serve and the variety of financial services they offer, while self-sustainability is achieved when the return on equity equals or exceeds the opportunity cost of funds. Similarly, Arsyad (2005) assessed the influence of MFIs by their sustainability and outreach. On the other hand, Zelle and Meyer (2002) added the social dimension to these two criteria and presented a framework to measure the performance with three-dimension criteria: outreach, financial sustainability, and the welfare impact. Moreover, the World Bank developed an index referred to as the 'Subsidy Dependence Index (SDI) (Francisco, 2008). Sanfeliu et al., (2013) proposed a goal programming based multi-criteria methodology in order to measure the performance of MFIs considering both the banking side and the social side. Zeller and Meyer (2002) identified the performance measurement in three critical dimensions: Repayment, staff productivity, and outreach. In agreement with the above, Rosenberg (2009) recommended a set of performance criteria that donors use in assessing the performance of MFIs. These are divided into two groups. Those are Social Dimensions - relating to the breadth and depth of outreach dimensions of social performance and financial indicators - relating to portfolio quality, financial sustainability, and efficiency.

In summary, whilst there are numerous attempts to evaluate the impact of ICT and mobile banking systems on organisational performances, there is research paucity when it comes to MFIs in particular. It is also evident that social media tools have prominent potentials for supporting MFIs. However, there 
are no definitive studies to assess the impact of social media on MFIs performance. With the identification of the main MFIs performance indicators, this paper aims to address this gap by evaluating the impact of social media on MFIs using the aforementioned indicators as the assessment catalysts.

\section{Research Model and Hypotheses Development}

The development of the research model is based on linking social media as an independent item with the various key performance indicators for MFIs leading to actual performance improvement. The model is represented in Figure 1. The following sections will give the hypothesis rationale for each of the links in the model.

\subsection{Social Media and Efficiency}

Efficiency is defined as the ability of an organisation to manage its operational costs (Barney, 1991; Melville et al., 2004 via Epelbaum and Martinez, 2014). Cubiles-De-La-Vega et al., (2013) addressed that for MFIs to survive at a long-term, the MFIs need to increase their efficiency, minimise their costs and control their credit risk. Anecdotal evidence suggests that organisations can benefit from their social media efforts in terms of efficiency (Cecere, 2010; Kane et al., 2014). Flanagin (2002) highlighted how social media could enhance the efficiency and help organisations to run their internal operations smoothly. Based on system generalised method of moments (GMM) estimation, Lam et al., (2016) showed that firms' social media initiatives improve operational efficiency and innovativeness. Zeiller and Schauer (2011) discussed the ability of organisation to benefit from using social media for team collaboration. They found that social media implementation in SMEs is associated with improvements in working processes. The growth of social media has provided millions of people the opportunity to create and share content on a scale barely conceivable a few years ago (Romero et al., 2011). Therefore, in the light of the above discussions, this research proposes the following hypothesis.

Hypothesis 1: Social media usage has a positive impact on the organisation's efficiency.

\subsection{Communication Performance}

As MFIs operate in geographically widespread areas, their administration costs increase as a result of high communication cost. As a channel of communication and platform for group discussion on different levels of responsibilities, social media has potentials to increase performance. For example, Moorhead et al., (2013) conducted a study on the use of social media for health communication among the general public, patients, and health professionals. They found that social media is a powerful tool that brings a new dimension to health care as it offers a medium to be used by the public, patients, and 
health professionals to communicate about health issues with the possibility of potentially improving health outcomes. Powell et al., (2011) suggested that social media provides an open platform for real time communication which gives the ability to the organisation to spot trouble, help customers, and reply to inquires much quicker than the traditional tools. On the other hand, Edosomwan et al., (2011) revealed that social media act as a powerful way to communicate the brand value and brand attribute as they facilitate open forms of communication. Lee (2015) presented extended evidence consistent with Greenwald (2010) that social media is a cost-effective tool for internal communication in organisations. Similarly, Khan and Khan (2011) confirmed that social media is able to develop better communication, stronger relationship and engagement between the management and employees. The above discussed evidences lead to proposing hypothesis 2 .

Hypothesis 2: The implementation of social media for MFIs improves their communication performance.

\subsection{Staff Productivity}

Aguenza et al., (2012) presented handful studies supporting the positive impact of social media on staff productivity. Lee (2015) and Burrus (2010) concluded that social media is an effective method to improve productivity and sharing information among organisational members. In addition, social media helps to increase the success of the organizations, enhance the creativity, and optimise the learning effect (Charband and Navimipour, 2016). Ferreira and Du Plessis (2009) found that this technology can be used to increase productivity through collaboration between individuals who share a common interest or goal. Social media is able to establish an inter-organisation platform where every staff member can present their knowledge and experiences offering others the opportunity to build strengthened relations and exchange of views (Siakas et al., 2014), to edit, revise, and alter organisational content long after the time it is first displayed, and also to find individuals with similar interests, or discover potential mentors (Treem and Leonardi, 2012). Therefore, in the light of the above discussion, this research proposes the following hypothesis.

Hypothesis 3: There is a positive impact of social media on the staff productivity.

\subsection{Social Media and Financial Sustainability (Profitability)}

The financial sustainability of an MFI is the capacity to recover all expenses from its revenues and to generate a margin to contribute toward its growth. In order to improve this indicator, MFIs are required 
to reduce the expenses and/or increase the revenues. Utilising social media as an effective communication platform and for marketing purposes will enable the organisations and businesses to reduce the costs comparing to the traditional methods (Colliander et al., 2015). Kappor et al., (2013) addressed the importance of social media to support stakeholder's interaction and engagement which was described by Piller et al., (2012) as supportive in the way to enhance the effectiveness and the efficiency of co-creation by lowering the cost of interaction among participants. Due to its interactive nature, Nascimento and da Silveira (2017) concluded that the user of social media platforms can create or change content in a way that is useful and profitable for organisations. In addition, social media holds enormous potentials on internal operations and efficiency, which will help the organisations to reduce their spending on operations (Baird and Parasnis, 2011). Therefore, in the light of the above discussion, this research proposes the following hypothesis.

Hypothesis 4: Social media usage can improve the organisation's financial sustainability.

\subsection{Social Media and Portfolio Quality (Loan Repayment)}

The lack of clear information on credit worthiness is one of the major challenges facing MFIs. Mitra and Newar (2015) addressed this problem through the use of social network. Social media could support the decision making process regarding loan worthiness with less cost and time. In addition, social media enables MFIs to improve the loan repayment in two stages: Pre-loan approval and repayment time. Norell (2001) discussed the issue of arrears in MFIs and suggests that the key to reducing arrears is a quick follow-up. Recent evidence from Tan et al., (2016) shows that, by using a combination of technology-enabled data and computational approaches, MFIs can develop effective credit scores for their applicants without the need for richer financial history or higher collaterals. Malekipirbazari and Aksakalli (2015) highlighted the importance of the vast amount of data on borrower characteristics on social networks such as Facebook and Twitter and they addressed the significant potential in mining of social media data for more accurate borrower risk attribution and thereby integration of social media into social lending. Furthermore, social media could play a great role as an instant communication tools to follow up with late payment. Social media can also help in promoting community pressure on defaulters. In-line with this discussion, Wakuloba (2006) confirmed the need for strengthening organisational management information systems for data mining to enable early detection of slow repayment borrowers. Therefore, in the light of the above discussion, this research proposes the following hypothesis.

Hypothesis 5: There is a direct positive impact of social media application on the institution's portfolio quality. 


\subsection{Social Media and Outreach}

Following the rapid technological development within the last two decades, traditional marketing methods became insufficient to accommodate the organisations and their client's needs. Geho and Dangelo (2012) discussed that social connectivity was becoming a key to marketing. Similarly, HennigThurau et al., (2010) (via Castronovo and Huang, 2012) settled that social media marketing works to effectively achieve the community creation and one-to-one relationship building to sell products and develop brand loyalty. The use of social media as a marketing method was massively increased in the past few years due to its great impact on the corporation image. Social media platforms provide decision maker with automatic measurement of customers' opinions of or attitudes toward specific products and services using their comments, which often reveal customer preferences (Jang et al., 2013). Evidence from Tajvidi and Karami (2017) confirmed that using social media improves the firms' marketing capabilities namely branding and innovation capabilities, which lead again to increased performance. Neti (2011) established that it is a strategic and methodical process to establish the company's influence, reputation and brand within communities of potential customers, readers or supporters. Furthermore, Treem and Leonardi (2012) discussed that social media afford new types of behaviours that were previously difficult or impossible to achieve before these new technologies entered the workplace. Hence, a call from researchers emerged to allocate more resources to be used for marketing through social media (Hudson and Thal, 2013; Neti, 2011). Social media is able to reach audiences at a scale and speed larger and more quickly than previous communication mediums (Hays et al., 2013).

Considering the microfinance industry, there is a need for effective marketing tool to offer the services to the underprivileged and also to keep them updated. Therefore, social media usage in MFIs helps the organisation to reach further people, offering those MFIs a sufficient saving comparing with the traditional marketing tools. Thus, the importance of social media for organisational outreach and communication was evident in the literature (Rimkuniene and Zinkeviciute, 2014; Linke and Zerfass, 2012; Zeiller and Schauer, 2011). Linke and Zerfass (2012) examined the use of social media for communication by enterprises, political organisations and non-profit organisations (NPOs). They concluded that due to their intensive positive impact, an ever increasing number of organisations establish the necessary and relevant structural conditions for social media communication and they expected that budgets for social media communication will rise as allocated from other sources. Therefore, in the light of the above discussion, this research proposes the following hypothesis.

Hypothesis 6: Social media usages in MFIs increases the outreach. 
Hence, based on the above discussions and the literature findings, the authors present the conceptual research model and hypotheses in Figure 1.

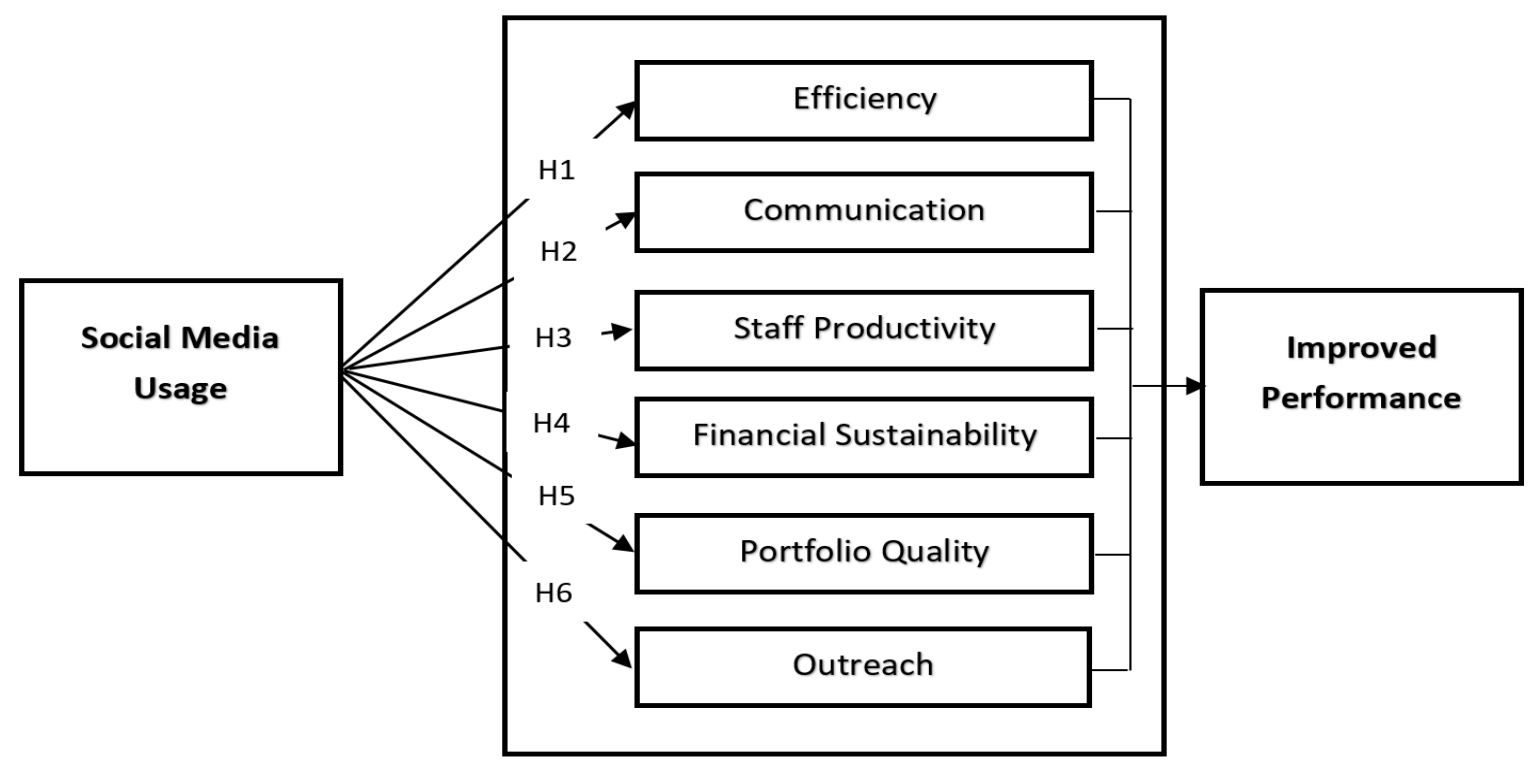

Figure 1: The Proposed Research Model

\section{Research Methodology: Survey Implementation}

In order to assess the impact of social media on the performance on MFIs, this study used survey questionnaire as a research strategy. A total of seven constructs (social media usage, MFI efficiency, the facilitated communication, staff productivity, financial sustainability, portfolio quality, and outreach) are designed with items adopted from previous studies. Items used to identify the types of social media implemented are adopted from Shang (2014); items to measure efficiency communication, staff productivity, financial sustainability, portfolio quality, and outreach are from Zhu and Kraemer (2005) and Picoto et al., (2012), Andriole (2010), Schaupp and Belanger (2013), Lee (2015), Zhu et al., (2006b), Rosenberg (2009), and Nanayakkara (2012). The study used the Likert scale for rating the questions (Bryman and Bell, 2007). Five points rating scale is used in this study where $1=$ strongly disagree, $2=$ disagree, $3=$ neutral, $4=$ agree, and $5=$ strongly agree .

\subsection{Data Collection Procedure}

The questionnaire was first distributed to experts and part of the targeted population to carry out a pilot testing. The questionnaire validity is obtained from a group of experts. They were asked to check the clarity and attractiveness of the questions. A first run of the refined questionnaire was sent out to the targeted population. Internal consistency is used to check the reliability of items loading on each 
construct and Cronbach's Alpha are used for this check (Hinton et al., 2004; Hair et al., 2010). Using MixMarket (2016) database, a list of microfinance institutions from developing countries was created. The list was filtered to keep only institutions that have implemented at least one type of social media platform. Emails were sent to around 1000 organisations. Bristol Online Survey (BOS) was used to run the survey online. A full required answer feature was designed, which prevents survey data submission unless certain items are responded to.

\subsection{Sample Profile}

A total of 383 valid responses were collected. The questionnaire included few questions regarding the demographic profile of the respondents: Just over $40 \%$ of the total respondents are females and the majority of the respondents are between 25-39 years old with 232 responses (60.6\%). More important, $118(30.8 \%)$ responses were completed from staff at the strategic level such as manager. In addition, the majority of respondents ( $84 \%$ ) claimed that they use social media for marketing purposes. Table 1 presents the full demographic profile.

Table 1: Sample Profile

\begin{tabular}{|c|l|c|c|}
\cline { 2 - 4 } \multicolumn{1}{c|}{ Item } & Frequency & Percentage \% \\
\hline \multirow{3}{*}{ Gender } & Male & 227 & 59.3 \\
\cline { 2 - 4 } & Female & 156 & 40.7 \\
\hline \multirow{3}{*}{ Position } & $24 \&$ less & 110 & 28.7 \\
\cline { 2 - 4 } & $25-39$ & 232 & 60.6 \\
\cline { 2 - 4 } & $40+$ & 41 & 10.7 \\
\hline \multirow{4}{*}{$\begin{array}{c}\text { The Purpose of } \\
\text { Use }\end{array}$} & Manager & 118 & 30.8 \\
\cline { 2 - 4 } & Staff & 265 & 69.2 \\
\cline { 2 - 4 } & Marketing \& Advertising & 322 & 80.7 \\
\cline { 2 - 4 } & Communication & 232 & 60.57 \\
\cline { 2 - 4 } & Mroduct sales \& Distribution & 222 & 57.96 \\
\cline { 2 - 4 } & Management & 203 & 53 \\
\hline
\end{tabular}

\subsection{Reliability and Validity}

Method biases are considered as a problem due to its effect in inflating the relationship between variables measured with the same method (Sharma et al., 2009). According to Podsakoff et al., (2003), one of the major sources of measurement error is method biases which threaten the validity of the assumption of relationship between measures. Harman's (1967) one-factor test was conducted in this study to check the severity of common method bias. The result of main components factor analysis 
shows seven factors each with an eigenvalue over than one. The result confirmed that there is no concern related to common method variance as the largest covariance explained by one factor is only $34.342 \%$. Kaiser-Meyer-Olkin (KMO) test is used to check multicollinearity as it calculates whether variables are so highly correlated that we cannot distinguish between them. The KMO value is found to be satisfactory $(0.922)$ and $p$ value is $<0.01$. In this research, content validity was checked first when all items were taken from previous studies, second by asking academics as they provided their comments and feedback, and third by undertaking pilot test of similar subject as the study's main population (MFIs employees). Few minor comments were taken and the questionnaire was adjusted accordingly.

Table 2: The Reliability and Validity Indicators

\begin{tabular}{|c|c|c|c|c|}
\hline Factor & $\begin{array}{c}\text { Number of } \\
\text { Items }\end{array}$ & Cronbach Alpha & $\begin{array}{c}\text { Inter-Item } \\
\text { Correlation }\end{array}$ & $\begin{array}{c}\text { Item-to-total } \\
\text { Correlation }\end{array}$ \\
\hline SMT & 7 & 0.644 & $0.14-0.530$ & $0.11-0.691$ \\
\hline EIO & 4 & 0.828 & $0.343-0.702$ & $0.566-0.757$ \\
\hline SP & 4 & 0.909 & $0.570-0.854$ & $0.644-0.874$ \\
\hline COM & 5 & 0.762 & $0.221-0.599$ & $0.432-0.674$ \\
\hline FS & 5 & 0.932 & $0.581-0.872$ & $0.757-0.902$ \\
\hline PQ & 4 & 0.966 & $0.820-0.947$ & $0.890-0.935$ \\
\hline BDO & 6 & 0.944 & $0.614-0.886$ & $0.749-0.864$ \\
\hline
\end{tabular}

\section{Results and Findings}

\subsection{Structural Equation Modelling}

The Structural Equation Modelling (SEM) technique using Analysis of Moment Structures (AMOS) version 20 , were used to validate the research hypotheses and the performance of its proposed model and explain the relationships, using confirmatory factor analysis (CFA) and the structural model (Hair et al., 2006). These are detailed in the following sections.

\subsubsection{Measurement Model (Confirmatory Factor Analysis)}

According to Asparouhov and Muthén, (2009), the CFA measurement model specifies a number of factor loadings fixed at zero to reflect the hypothesis that certain factors influence indicators. Following the recommendation of Hair et al., (2006) to assess the measurement model, two main approaches were used: 1) deliberation goodness of fit (GOF) criteria indices; and (2) construct validity approach. The CFA was conducted on 7 constructs along with 34 items. The constructs are: social media type (SMT), efficiency (EIO), staff productivity (SP), communication efficiency (COM), financial sustainability (FS), portfolio quality (PQ), and breadth and depth of outreach (BDO). They were all loaded with their own measurements and examined as explained in Table 2. 
Table 3: Goodness of Fit for CFA

\begin{tabular}{|l|c|c|}
\hline \multicolumn{1}{|c|}{ Indices } & Default Model & Suggested Criteria \\
\hline RMSEA & 0.069 & $<0.08$ \\
PCLOSE & 0.000 & $<0.05$ \\
\hline & & \\
\hline$x^{2} / d f$ & 2.831 & $1: 5$ \\
$P$ & 0.000 & $\leq 0.001$ \\
\hline & & \\
\hline CFI & 0.918 & Close to 0.90 \\
\hline IFI & 0.918 & Close to 0.90 \\
\hline TLI & 0.903 & Close to 0.90 \\
\hline
\end{tabular}

Furthermore, according to Hair et al., (2010), minimum of four tests of model fit need to be considered, as presented in Table 2, the cut-off points were considered as suggested by Hu and Bentler (1999) to be compared with the default model value; the results show good fit for the measurement model.

Table 4: Summary Results of Convergent Validity

\begin{tabular}{|c|c|c|c|c|}
\hline Construct & Item & $\begin{array}{c}\text { Factor } \\
\text { Loadin } \\
\text { g } \\
\end{array}$ & $\mathbf{C R}$ & AVE \\
\hline \multirow{6}{*}{$\begin{array}{c}\text { Social Media Types } \\
\text { (SMT) }\end{array}$} & Picture and video broadcasting websites & 0.558 & \multirow{6}{*}{0.859} & \multirow{6}{*}{0.515} \\
\hline & Social networking website & 0.493 & & \\
\hline & Product review system website & 0.654 & & \\
\hline & Microblogging & 0.899 & & \\
\hline & Blogs & 0.825 & & \\
\hline & Document management & 0.788 & & \\
\hline \multirow{4}{*}{ Efficiency (EIO) } & Internal operations more efficient & 0.866 & \multirow{4}{*}{0.919} & \multirow{4}{*}{0.739} \\
\hline & Improved decision making & 0.872 & & \\
\hline & Reduce administration workload & 0.836 & & \\
\hline & Better information quality & 0.865 & & \\
\hline \multirow{5}{*}{$\begin{array}{c}\text { Communication } \\
\text { (COM) }\end{array}$} & Facilitate communication among employees & 0.778 & \multirow{5}{*}{0.907} & \multirow{5}{*}{0.662} \\
\hline & Facilitate communication with customers & 0.766 & & \\
\hline & Ability to audit communications streams & 0.818 & & \\
\hline & Improved communication performance & 0.892 & & \\
\hline & Ability to reach more people faster & 0.809 & & \\
\hline \multirow{4}{*}{$\begin{array}{l}\text { Staff Productivity } \\
\text { (SP) }\end{array}$} & Staff productivity increased & 0.842 & \multirow{4}{*}{0.913} & \multirow{4}{*}{0.725} \\
\hline & Increased staff motivation and satisfaction & 0.713 & & \\
\hline & Improved employee effectiveness & 0.919 & & \\
\hline & Easier for the staff to do their job & 0.915 & & \\
\hline \multirow{5}{*}{$\begin{array}{c}\text { Financial } \\
\text { Sustainability (FS) }\end{array}$} & Increased profitability & 0.906 & \multirow{5}{*}{0.920} & \multirow{5}{*}{0.701} \\
\hline & Operational costs decreased & 0.950 & & \\
\hline & Reduced marketing costs & 0.724 & & \\
\hline & Inventory costs decreased & 0.654 & & \\
\hline & Total cost decreased & 0.912 & & \\
\hline \multirow{4}{*}{$\begin{array}{l}\text { Portfolio Quality } \\
\text { (PQ) }\end{array}$} & Improved loan repayment & 0.876 & \multirow{4}{*}{0.959} & \multirow{4}{*}{0.854} \\
\hline & Decreased portfolio at risk & 0.933 & & \\
\hline & Decreased defaults rate & 0.946 & & \\
\hline & Decreased arrears rate & 0.939 & & \\
\hline
\end{tabular}




\begin{tabular}{|c|l|l|l|l|}
\hline \multirow{4}{*}{\begin{tabular}{c|l|l|} 
Outreach \\
(BDO)
\end{tabular}} & Outreach increased & 0.843 & & \multirow{3}{*}{0.841} \\
\cline { 2 - 3 } & Outreach area widened & \multirow{3}{*}{0.932} & \multirow{3}{*}{0.695} \\
\cline { 2 - 3 } & Increase convenience / service level to the clients & 0.870 & \\
\cline { 2 - 3 } & Improved marketing flexibility & 0.807 & & \\
\cline { 2 - 3 } & Increased control of direct marketing objectives & 0.820 & & \\
\cline { 2 - 3 } & Deeper outreach & 0.818 & & \\
\hline
\end{tabular}

- Construct Validity and Reliability: It is very important to check the validity and reliability of the measures before proceeding to test the proposed model hypothesis as this affect the outcome of the research (Hair et al., 2010). Both validity and reliability should be checked as a measure may have high reliability (consistency) but not be valid (accurate), and a measure may have high validity (accuracy) but not be reliable (consistent) (Holmes-Smith, 2001). Three indicators are used to evaluate the convergent validity: composite reliability (CR), average variance extracted (AVE), and factor loading. The results, as presented in Table 3, show that all the values of factor loading, CR, and AVE are regarded as satisfactory.

- Discriminant Validity: Discriminant validity can be assessed by comparing the AVE values for any two constructs with the square of correlation estimate between these two constructs. Discriminant validity is significant when AVE is greater than squared correlation estimates between constructs. The result shown in Table 3, highlights a significant level of discriminant validity as AVE is greater than the squared correlation estimate for all the constructs. In addition, Table 4 presents correlations and discriminant validity of the constructs.

Table 5: Correlations and Discriminant Validity of the Constructs

\begin{tabular}{|c|c|c|c|c|c|c|c|}
\cline { 2 - 8 } \multicolumn{1}{c|}{} & SMT & EIOS & SP & COM & FS & PQ & BDO \\
\hline SMT & $\mathbf{0 . 7 1 8}$ & - & - & - & - & - & - \\
\hline EIOS & -0.230 & $\mathbf{0 . 8 6 0}$ & - & - & - & - & - \\
\hline SP & -0.163 & 0.814 & $\mathbf{0 . 8 5 1}$ & - & - & - & - \\
\hline COM & -0.234 & 0.707 & 0.683 & $\mathbf{0 . 8 1 4}$ & - & - & - \\
\hline FS & -0.044 & 0.552 & 0.584 & 0.443 & $\mathbf{0 . 8 3 7}$ & - & - \\
\hline PQ & 0.340 & 0.137 & 0.132 & 0.124 & 0.272 & $\mathbf{0 . 9 2 4}$ & - \\
\hline BDO & -0.189 & 0.521 & 0.580 & 0.557 & 0.536 & 0.135 & $\mathbf{0 . 8 3 3}$ \\
\hline
\end{tabular}

\subsection{Hypotheses Testing}

After testing the validity of CFA, it is the time to confirm the research hypotheses by testing the structural model which empirically identifies the relations between the factors. First, there is a need to check the model fit as presented in Table 5, acceptable value of RMSEA was found indicating good git associated with PCLOSE less than 0.05 , in addition, CFI, IFI, and TLI were very close to 0.9 which is 
also accepted per the suggested value of $\mathrm{Hu}$ and Bentler (1999). Chi-squared was also in the range $>1$ and $<5$ associated with significant $p$-value.

In addition, this paper considered analysing the path significant of each relationship, where it examined the standardised estimate (S.E), critical ratios (C.R) and p-value for each proposed relationship. A relationship is significant when a t-value is above 1.96 and a p-value of $(\leq .05)$. A $t$-value can be calculated by dividing the regression weight estimate by standard error (S.E).

Table 6: Goodness of Fit for Structural Model

\begin{tabular}{|l|c|c|}
\hline \multicolumn{1}{|c|}{ Indices } & Default Model & Suggested Criteria \\
\hline RMSEA & 0.078 & $<0.08$ \\
PCLOSE & 0.000 & $<0.05$ \\
\hline & & \\
\hline$x^{2} / d f$ & 3.322 & $\leq 0.001$ \\
$P$ & 0.000 & $>0.90$ \\
\hline & & Close to 0.90 \\
\hline CFI & 0.898 & Close to 0.90 \\
\hline IFI & 0.899 & \\
\hline TLI & 0.884 & \\
\hline
\end{tabular}

Therefore, the regression weight estimates of the six hypotheses in this study are presented in Table 6, and all the results indicate that all casual paths for these six hypotheses are significant with the t-values above 1.96 and the $p$-value is $\leq 0.05$. Thus, the modified model is presented in Figure 2 .

Table 7: Results of Hypotheses Testing

\begin{tabular}{|c|c|c|c|c|c|c|}
\hline Hypotheses & Variables & Estimate & S.E & C.R & $P$ & Outcome \\
\hline 1: $\mathrm{H} 1$ & $\mathrm{SMT} \rightarrow \mathrm{EIO}$ & 0.872 & 0.145 & 6.004 & $* * *$ & Supported \\
\hline 2: $\mathrm{H} 2$ & $\mathrm{SMT} \rightarrow \mathrm{COM}$ & 0.296 & 0.077 & 3.866 & $* * *$ & Supported \\
\hline 3: H3 & $\mathrm{SMT} \rightarrow \mathrm{SP}$ & 0.670 & 0.127 & 5.289 & $* * *$ & Supported \\
\hline 4: $\mathrm{H} 4$ & $\mathrm{SMT} \rightarrow \mathrm{FS}$ & 0.286 & 0.122 & 2.338 & 0.019 & Supported \\
\hline 5: H5 & $\mathrm{SMT} \rightarrow \mathrm{PQ}$ & 0.937 & 0.164 & 5.702 & $* * *$ & Supported \\
\hline 6: H6 & $\mathrm{SMT} \rightarrow \mathrm{BDO}$ & 0.219 & 0.080 & 2.729 & 0.006 & Supported \\
\hline
\end{tabular}

The results illustrate a significant relationship between social media and efficiency with a path coefficient of 0.872 , critical ratio of 6.004 , and a $p$-value less than 0.05 . This means that the hypothesis H1 is supported. Similarly, a path coefficient for the proposed relationship between social media and staff productivity is 0.670 with a t-value of 5.289 and $p$-value of 0.000 which support (H2) hypothesis. The results also show a significant relationship between social media and communication (H3) with 0.296 a path coefficient, 3.866 critical ratio and p-value less than 0.05 . Regarding the relationship between the social media usage and the financial sustainability $(\mathrm{H} 4)$, the results revealed a $t$-value of 
$2.338(>1.96)$ and $p$-value less than 0.05 so the path coefficient of 0.286 indicates a significant relationship between the factors. The results also support the significant relationship between both social media usage and portfolio quality (H5) with a path coefficient of $0.937, t$-value of 5.702, and $p$ value less than 0.05 . The last hypothesis (H6), is also supported and the relationship between the social media usage and breadth and depth of outreach is significant with a path estimate of $0.219, t$-value of 0.729 , and p-value of 0.006 .

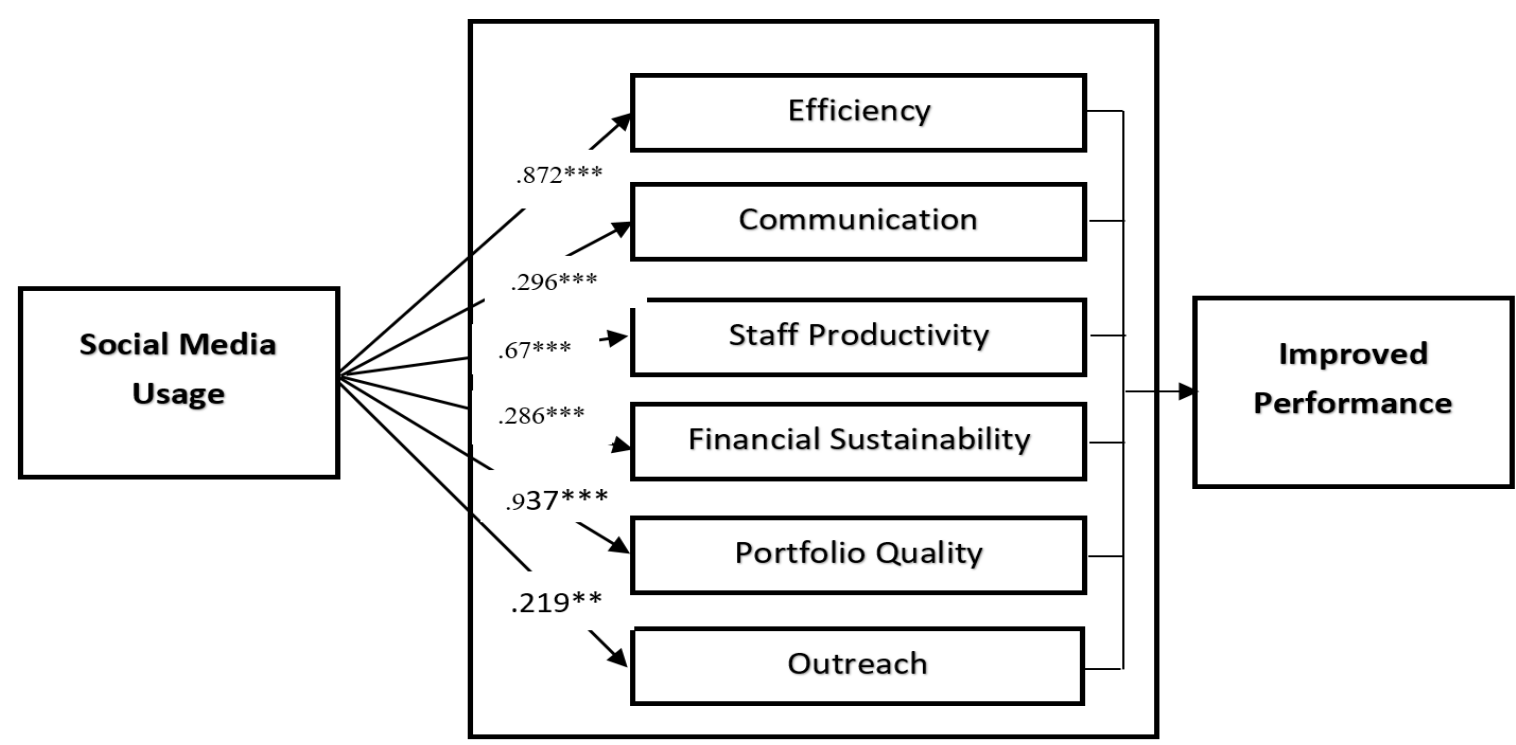

Figure 2: The Modified Model

\section{Discussion}

The results, as shown in Figure 2, support the claim of positive impact of social media usage on efficiency, communication, and staff productivity. These results are consistent with previous research that social media holds enormous potential for organisations, such as Baird and Parasnis (2011) and Schaupp and Belanger (2013). Hence, the findings confirm that there is a significant impact for the use of social media in terms of increasing financial sustainability $(\mathrm{H} 4)$ by reducing the overall costs and/or increasing the revenues. As from the sample, 232 (60.6\% of the total responses) claimed that they use social media for communication in addition to $58 \%$ claimed that they use it for product sales and distribution. These findings are in line with Kim et al., (2015) study on the effectiveness of social media and its critical role as a marketing tool. Social media can be considered as communication tool with ability to include marketing, customer services, public relations, lead generation, and market research (Powell et al., 2011). It would be a useful platform for microfinance entities that do not have further budgets for marketing and services. 
Another interesting finding (related to H5), is that the highest impact of social media usage within the microfinance is on the portfolio quality. The results proved that social media have numerous potentials to improve the performance of loan repayment, such as following up with the clients and addressing the late borrowers and encouraging them to pay under the social pressure. This is also consistent with Tan and Phan (2016), who concluded that when financial services find it difficult to assess creditworthiness for borrowers with no finance background; online social networks might provide an efficient data source and offer useful information about the borrowers. These findings are also complementary to the literature and confirm that; fully implementing social media is expected to enhance collaboration, increase efficiency, and reduce the costs (e.g. Blanchard, 2011). Better performance should necessarily mean better use of the available resources, and consequently increasing the outreach (H6).

Moreover, sufficient proof from the literature has confirmed the ability of social media to reduce the geographical distance between the clients and the branches (Tajvidi and Karami, 2017; Rimkuniene and Zinkeviciute, 2014; Linke and Zerfass, 2012; Zeiller and Schauer, 2011). Social media might be used to extend not only the breadth of outreach, but also the depth of outreach. Increasing depth of outreach by extending the supply of microfinance products to a particular target group is one of the critical issues for MFIs. There is a consensus that it is socially more important to expand the frontier of finance for the poor than it is to further expand the frontier of finance for the rich (Morduch et al., 2005; Gulli, 1998) (via Robert et al., 2013).

This piece of research, also, reveals that social networking websites is number one tool for the organisations that already employed social media. The second most widely used tool as revealed is picture and video broadcasting websites, followed by product review system websites. The findings also revealed that $80 \%$ of the MFIs, which deployed social media, are using it for marketing and advertising purposes, in addition to $60 \%$ who use it for communications, 58\% who use it for product sales and distribution, and 53\% who use it for managerial purposes.

\subsection{Theoretical Contribution and Practical Implications}

This paper adds to the existing body of knowledge from theoretical and practical viewpoints, such as:

- This research developed a model for assessing the value of social media as a new phenomenon within this type of organisation. Although, scholars have identified the impact of different type of technology employed by MFIs such as mobile banking and other ICT tools (Moya Musa et al., 2012; Asongu et al., 2018a; b), very limited research has considered the significance of social media on the organisational performance. According to Kaplan and Haenlein (2012), social media still offers a unique opportunity for academics to help organisations to be ready 
for this new age of internet and smart-phones applications. The current study tried to fill this gap and provide a wide view of when and where social media technologies can help organisations and business managers in term of their performance improvement.

- This research offers microfinance sponsors, managers, and policy makers with a frame of reference to understand what type social media technologies/platform can be deployed for the purpose of improving business performance. Our findings show that social networking websites are the most popular platforms within microfinance industry, in addition marketing and advertising, communication, sales and distribution are the main areas where social media is able to support.

- With the identification of the main MFIs performance indicators (namely, efficiency, repayment, sustainability, and outreach), this research have provided a reference of performance measurement guide for microfinance industry when in assessing different technological employment. This assessment take into account both financial performance and social mission

- The model proposed in this study can be used in practice to guide decision makers in MFIs, on building the organisation's social media profile in the light of their needs alongside with the traditional marketing and communication tools. This may, also, enable them to widen the coverage and remove the geographical barrier by getting closer to their current as well as potential clients.

\section{Conclusions, Limitations and Future Research Directions}

This study focused on the significance of social media and presented a conceptual model for evaluating its impact on the performance of MFIs. The model was examined by quantitative approach collecting 383 responses from MFIs employees where at least one social media platform is deployed; all the hypotheses were empirically investigated and were found to be supported. This study attempted to provide more understanding to the importance of social media usage within the MFIs in order to face their challenges and improve their performance. Such understanding is believed to help the microfinance industry to better meet the increasing demand on micro-financial services. In Addition, this study has theoretically contributed to the field of organisational performance. To the best of the authors' knowledge, linking the three bodies of research (social media, microfinance industry, and organisational performance) has not previously been attempted. Previous research on microfinance development has only focused on the use of ICT and mobile banking technology. Moreover, in response to calls from practices for new and better ways of measuring MFI performance, the combination of key performance indicators used in this study to measure the social media effect also can be used for assessing the progress of MFI performance after implementing new tools, strategies, and plans. 
By employing social media use within MFIs, we attain few configurations of elements resulting in superior financial and operational performance. They are grouped into clusters of patterns based on the difficulties they face. For MFIs that facing difficulties with marketing and advertisement, both of social networking websites, pictures and video broadcasting websites are very helpful in this context. The statistical evidence of this study confirmed that there is a correlation between these two social media types and the purpose of using them for marketing. Social media can serve as an effective marketing tool in business, valuable for both consumers and companies, offering a wide range of opportunities (Kaplan and Haenlein, 2010). In their study, Mariani et al., (2016) explored how Italian regional Destination Management Organisations (DMOs) strategically employ Facebook to promote and market their destinations, and improves on the current metrics for capturing user engagement.

For MFIs facing issues with communication (whether it is mass communication or individual client, whether it is external or internal), microblogging and messaging apps (such as Twitter, Facebook Messenger, WhatsApp, Telegram, and Viber) can fit for this purpose and help organisations to ease the operation (Java et al., 2017; Honey and Herring, 2009). Our study experienced how social media is linked with rural areas to the centre through such commination tools reducing the cost and the distance. Furthermore, for MFIs struggling with product design, sale, and distribution, it is vital to employ the use of product review system website. More than half of this research's participants claimed that they employ social media for this purpose. This finding is also similar with the conclusions of Liu et al., (2011). However, although some social media types can be more effective in some contexts than in others, the nature and the structure of the organisation plays a significant role on designing the best mix of social media profile and it is worth trying more than one media on the same task in order to test the more effective one.

\subsection{Limitations}

The authors recognise that our study has limitations, and readers and future academics and researchers should be aware of these and indeed interpret the material presented in this paper within the context of the limitations. For instance:

- By using the term social media, the research included all types of social media in this investigation and treated them equally. However, different communities are engaged to different types of social media and different organisations may implement different types based on the purpose of such implementation.

- By the use of self-administrated survey, the current work has quantitatively examined the suggested conceptual model. Hence, the limitation of using such tools is that it bounds the 
capability of accessing the in-depth view of social media benefits on each of the performance indicators.

- There was a requirement for convenient sampling to collect the data, which limits the capability to guarantee the validity of generalising the results of a small sample to the whole population.

- Lastly, another limitation is related to empirical investigation of this study i.e. a sample from the developing countries was conducted; the limitation of this sample is that it does not take into account the socio-economics characteristics of population from different countries and different backgrounds.

\subsection{Future Research Directions}

Building upon the rich foundation of the research findings described and overall understanding acquired in here, the authors presented a number of issues that merit further research and anticipate that these issues may hold the potential in contributing towards the future research studies. For example:

- Future research may use a content analysis technique for systematically describing the use of social media for microfinance communication. In addition, further studies could consider one social media platform such as Twitter or Facebook within one country or region. Each type of social media and its use within specific geographical area could be another path of research.

- Future research can validate the impact of social media on the performance of MFIs qualitatively by the use of interviews or focus groups, as it will enable the researcher to have in depth views of MFI management and employees, which will allow the extraction of more factors of social media value. In addition, there is a need for research on the use of social media within the MFI for each of the performance indicators. For example, future studies may further clarify the best use of social media for marketing purposes benefiting from the advantages of case study methodology.

- Further study could address our limitation on being very specific on the depth of social media usage and link it to the impact, taking into account different social media platforms separately.

- Investigating the challenges of adopting social media technologies by microfinance institutions could be another path for future research studies. More focus is needed on the acceptance and engagement of the microfinance industry stakeholders related to social media adoption and acceptance.

\section{References}


Abraham, R. (2007). Mobile phones and economic development: evidence from the fishing industry in India. Information Technologies and International Development, 4(1), 5-17.

Acha Ikechukwu, A. (2012). Microfinance Banking in Nigeria: Problems and Prospects. International Journal of Finance and Accounting, 1(5), 106-111.

Al-Jabri, I. M., \& Sohail, M. S. (2012). Mobile banking adoption: Application of diffusion of innovation theory. Journal of Electronic Commerce Research, 13(4), 379-391.

Ahlin, C., Lin, J., \& Maio, M. (2011). Where does microfinance flourish? Microfinance institution performance in macroeconomic context. Journal of Development Economics, 95(2), 105-120.

Amelec, V., \& Carmen, V. (2015). Relationship between Variables of Performance Social and Financial of Microfinance Institutions. Advanced Science Letters, 21(6), 1931-1934.

Arsyad, L. (2005). An assessment of microfinance institution performance. Gadjah Mada International Journal of Business, 7(3).

Ashraf, M., Hanisch, J., \& Swatman, P. (2009). ICT intervention in the 'Chandanbari' Village of Bangladesh: Results from a field study. Information Systems Frontiers, 11(2), 155-166.

Ashraf, M., Grunfeld, H., Hoque, M. R., \& Alam, K. (2017). An extended conceptual framework to understand information and communication technology-enabled socio-economic development at community level in Bangladesh. Information Technology \& People, 30(4), 736-752.

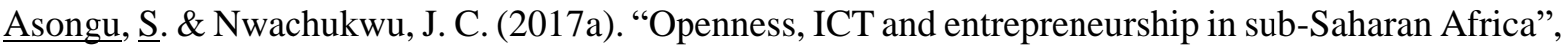
Information Technology \& People, in press: https://doi.org/10.1108/ITP-02-2017-0033

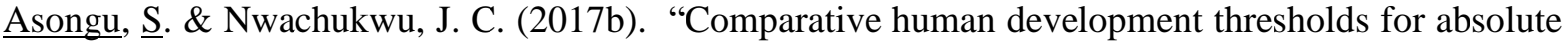
and relative pro-poor mobile banking in developing countries", Information Technology \& People, in press: https://doi.org/10.1108/ITP-12-2015-0295

Augsburg, B., Schmidt, J. P., \& Krishnaswamy, K. (2011). Free \& Open Source Software for Microfinance: Increasing Efficiency and. Advanced Technologies for Microfinance, 18

Baird, C., \& Parasnis, G. (2011). From social media to social customer relationship management. Strategy \& Leadership, 39(5), 30-37.

Blanchard, O. (2011). Social media ROI: Managing and measuring social media efforts in your organization. Pearson Education.

Brau, J. C., \& Woller, G. M. (2004). Microfinance: A comprehensive review of the existing literature. Journal of Entrepreneurial Finance, JEF, 9(1), 1-27.

Bryman, A. and Bell, E. (2011) Business Research Methods 3rd ed., New York: Oxford University Press.

Bughin, J. (2008). The rise of enterprise 2.0. Journal of Direct, Data and Digital Marketing Practice, 9(3), 251-259

Bulearca, M., \& Bulearca, S. (2010). Twitter: a viable marketing tool for SMEs? Global Business and Management Research: An International Journal, 2(4), 296-309. 
Castronovo, C., \& Huang, L. (2012). Social media in an alternative marketing communication model. Journal of Marketing Development and Competitiveness, 6(1), 117.

Cecchini, S., \& Scott, C. (2003). Can information and communications technology applications contribute to poverty reduction? Lessons from rural India. Information Technology for Development, 10(2), 73-84.

Cecere, L. (2010). The rise of social commerce. A Trail Guide for the Social Commerce Pioneer. Altimeter Group, San Mateo, CA.

Charband, Y., \& Navimipour, N. J. (2016). Online knowledge sharing mechanisms: a systematic review of the state of the art literature and recommendations for future research. Information Systems Frontiers, 18(6), 1131-1151.

Charitonenko, S., \& Campion, A. (2003). Expanding Commercial Microfinance in Rural Areas: Constraints and Opportunities. In Paving the Way Forward: An International Conference on Best Practice on Rural Finance. Washington, DC June (Vol. 2).

Chung, S., \& Park, J. (2017). Exploring consumer evaluations in social media: The role of psychological distance between company and consumer. Computers in Human Behavior, 76, 312-320.

Colliander, J., Dahlén, M., \& Modig, E. (2015). Twitter for two: investigating the effects of dialogue with customers in social media. International Journal of Advertising, 34(2), 181-194.

Comrey, A. L. \& Lee, H. B. (1992) A First Course in Factor Analysis. L. Erlbaum Associates.

Creswell, J. W. (1994). Research design: Qualitative and quantitative. SAGE Publications, Inc; annotated edition (27 Jun. 1994)

Cubiles-De-La-Vega, M. D., Blanco-Oliver, A., Pino-Mejías, R., \& Lara-Rubio, J. (2013). Improving the management of microfinance institutions by using credit scoring models based on Statistical Learning techniques. Expert Systems with Applications, 40(17), 6910-6917.

Cull, R., Demirgüç-Kunt, A., \& Morduch, J. (2010). Microfinance meets the market. Contemporary Studies in Economic and Financial Analysis, 92, 1-30.

Davidson, D. (2009) How to...put a price on your social media strategy, Revolution Magazine - The Insider's Guide to Digital Marketing 2009, November, pp.29-33;

Davison, R. M., \& Ou, C. X. (2017). Digital work in a digitally challenged organization. Information \& Management, 54(1), 129-137.

De Marcellis-Warin N., Sanger W. and Warin T. (2017) 'A network analysis of financial conversations on Twitter'. International Journal of Web Based Communities (IJWBC), Vol. 13, No. 3, 2017.

Dey, B., Newman, D. and Prendergast, R. (2011). Analysing appropriation and usability in social and occupational lives: An investigation of Bangladeshi farmers' use of mobile telephony. Information Technology and People, 24(1), 46-63.

Dichter, T. and M. Harper, eds, (2007). What's Wrong with Microfinance? Rugby: PA Publications.

Diniz, E. H., Pozzebon, M., \& Jayo, M. (2008). Banking technology to scale microfinance: the case of correspondent banking in Brazil. ICIS 2008 Proceedings, 144. 
Divol, R., Edelman, D., \& Sarrazin, H. (2012). Demystifying social media. McKinsey Quarterly, 2(12), 66-77.

Edosomwan, S., Prakasan, S. K., Kouame, D., Watson, J., \& Seymour, T. (2011). The history of social media and its impact on business. Journal of Applied Management and entrepreneurship, 16(3), 79.

Epelbaum, F. M. B., \& Martinez, M. G. (2014). The technological evolution of food traceability systems and their impact on firm sustainable performance: A RBV approach. International Journal of Production Economics, 150, 215-224.

Ferreira, A., \& Du Plessis, T. (2009). Effect of online social networking on employee productivity. South African Journal of Information Management, 11(1), 1-11.

Flanagin, A. J. (2002). The elusive benefits of the technology support of knowledge management. Management Communication Quarterly: McQ,16(2), 242.

Francisco, M. (2008). Measuring the performance and achievement of social objectives of development finance institutions (Vol. 4506). World Bank Publications.

Geho, P. R., \& Dangelo, J. (2012). The evolution of social media as a marketing tool for entrepreneurs. The Entrepreneurial Executive, 17, 61.

Gray, B., Weal, M., \& Martin, D. (2016). Social media and disasters: A new conceptual framework.The ISCRAM 2016 Conference - Rio de Janeiro, Brazil, May 2016

Gray, D.E. (2014) Doing Research in the Real World 3rd edn, London, SAGE Publications Ltd.

Grover, V., Gokhale, R. A., \& Narayanswamy, R. S. (2009). Resource-based framework for IS research: Knowledge firms and sustainability in knowledge markets. Journal of the Association for Information Systems, 10(4), 306.

Gül S., Kabak Ö. and Topcu I. (2018) 'A multiple criteria credit rating approach utilizing social media data'. Data \& Knowledge Engineering, 116, 80-99

Gulli, H. (1998). Microfinance and poverty: Questioning the conventional wisdom. Washington, DC: Inter-American Development Bank.

Hair, J. F., Sarstedt, M., Kuppelwieser, V., \& Hopkins, L. (2014). Partial Least Squares Structural Equation Modeling (PLS-SEM): An Emerging Tool for Business Research. European Business Review, 26(2).

Hair, J.F., Black, W. C., Babin, B.J. and Anderson, R.E. (2010) Multivariate data analysis, 7th edn. New York, Pearson.

Hays, S., Page, S. J., \& Buhalis, D. (2013). Social media as a destination marketing tool: its use by national tourism organisations. Current Issues in Tourism, 16(3), 211-239.

He, W., \& Yang, L. (2016). Using wikis in team collaboration: A media capability perspective. Information \& Management, 53(7), 846-856. 
Hennig-Thurau, T., Malthouse, E. C., Friege, C., Gensler, S., Lobschat, L., Rangaswamy, A., \& Skiera, B. (2010). The impact of new media on customer relationships. Journal of service research, 13(3), 311-330.

Hentschel, M., \& Alonso, O. (2014). Follow the money: A study of cashtags on Twitter. First Monday, 19(8).

Holmes-Smith, P. (2001). Introduction to structural equation modeling using LISREL. Perth: ACSPRIWinter training Program.

Holtz, S., \& Havens, J. C. (2008). Tactical transparency: How leaders can leverage social media to maximize value and build their brand. Jossey-Bass, San Francisco, CA

Honey, C., \& Herring, S. C. (2009, January). Beyond microblogging: Conversation and collaboration via Twitter. In 2009 42nd Hawaii International Conference on System Sciences (pp. 1-10). Ieee.

Hudson, S., \& Thal, K. (2013). The impact of social media on the consumer decision process: Implications for tourism marketing. Journal of Travel \& Tourism Marketing, 30(1-2), 156-160.

Huy, Q., \& Shipilov, A. (2012). The key to social media success within organizations. MIT Sloan Management Review, 54(1), 73.

Hudon, M., \& Traca, D. (2011). On the efficiency effects of subsidies in microfinance: An empirical inquiry. World development, 39(6), 966-973.

Jang, H. J., Sim, J., Lee, Y., \& Kwon, O. (2013). Deep sentiment analysis: Mining the causality between personality-value-attitude for analyzing business ads in social media. Expert Systems with applications, 40(18), 7492-7503.

Java, A., Song, X., Finin, T., \& Tseng, B. (2007, August). Why we twitter: understanding microblogging usage and communities. In Proceedings of the 9th WebKDD and 1st SNA-KDD 2007 workshop on Web mining and social network analysis (pp. 56-65). ACM.

Kaminski J., Hopp C. and Lukas C. (2018) 'Who benefits from the wisdom of the crowd in crowdfunding? Assessing the benefits of user-generated and mass personal electronic word of mouth in computer-mediated financing'. Journal of Business Economics. 88, 1133-1162

Kanayo, O., Jumare, F., \& Nancy, S. (2013). Challenges of Microfinance Access in Nigeria: Implications for Entrepreneurship Development.Mediterranean Journal of Social Sciences, 4(6), 611.

Kanayo, O., Jumare, F., \& Nancy, S. (2013). Challenges of Microfinance Access in Nigeria: Implications for Entrepreneurship Development.Mediterranean Journal of Social Sciences, 4(6), 611.

Kane, G. C. J., Palmer, D., Phillips, A. N., Kiron, D., \& Buckley, N. (2014). Moving beyond marketing: Generating social business value across the enterprise. MIT Sloan Management Review, 56(1), 1.

Kim, W. G., Lim, H., \& Brymer, R. A. (2015). The effectiveness of managing social media on hotel performance. International Journal of Hospitality Management, 44, 165-171. 
Kneiding, Ch. \& Rosenberg, R. (2008). Variations in microcredit Interest rates. Consultative Group to Assist the Poor (CGAP) Policy Brief, July 2008

Kumar, V., \& Mirchandani, R. (2012). Increasing the ROI of social media marketing. MIT Sloan Management Review, 54(1), 55.

Lacho, K. J., \& Marinello, C. (2010). How small business owners can use social networking to promote their business. The Entrepreneurial Executive, 15, 127-133.

Lam, H. K., Yeung, A. C., \& Cheng, T. E. (2016). The impact of firms' social media initiatives on operational efficiency and innovativeness. Journal of Operations Management, 47, 28-43.

Linke, A., \& Zerfass, A. (2012). Future trends in social media use for strategic organisation communication: Results of a Delphi study. Public Communication Review, 2(2), 17-29.

Liu, Q. B., Karahanna, E., \& Watson, R. T. (2011). Unveiling user-generated content: Designing websites to best present customer reviews. Business Horizons, 54(3), 231-240.

Lyon, T. P., \& Montgomery, A. W. (2013). Tweetjacked: The impact of social media on corporate greenwash. Journal of business ethics, 118(4), 747-757.

Mahboub, R.M. (2018). 'The Impact of Social Media Usage on Performance of the Banking Sector in Middle East and North Africa Countries'. International Journal of Economics and Business Administration. Volume VI, Issue 3.

Malekipirbazari, M., \& Aksakalli, V. (2015). Risk assessment in social lending via random forests. Expert Systems with Applications, 42(10), 4621-4631.

Mariani, M. M., Di Felice, M., \& Mura, M. (2016). Facebook as a destination marketing tool: Evidence from Italian regional Destination Management Organizations. Tourism Management, 54, 321-343.

Mas, I., \& Radcliffe, D. (2011). Mobile Payments Go Viral: M-PESA in Kenya. Journal of Financial Transformation, 32, 169-182.

McAfee, A. P. (2006). Enterprise 2.0: The dawn of emergent collaboration. MIT Sloan Management Review, 37(3), 21-28.

McIntyre, G. (2012). Microfinance: An Analysis of Success and Challenges in West Africa. 2012 NCUR.

Mendoza, R. U. (2011). Why do the poor pay more? Exploring the poverty penalty concept. Journal of International Development, 23(1), 1-28.

Mikalef, P., \& Pateli, A. G. (2017). Social Media for Open Innovation: A Study of Adoption Determinants. In the Proceedings of the Pacific Asia Conference on Information Systems (PACIS2017), p. 219-232.

Mithas, S., Tafti, A. R., Bardhan, I., \& Goh, J. M. (2012). Information technology and firm profitability: mechanisms and empirical evidence. Mis Quarterly, 36(1), 205-224.

Mitra, S., \& Newar, V. (2015). Helping a Microfinance Institution Select its Clients: A Risk Analysis using Social Networks. Black \& Gold, 1(1), 6 . 
Moorhead, S. A., Hazlett, D. E., Harrison, L., Carroll, J. K., Irwin, A., \& Hoving, C. (2013). A new dimension of health care: systematic review of the uses, benefits, and limitations of social media for health communication. Journal of medical Internet research, 15(4), e85.

Morduch, J. (2000). The microfinance schism. World development, 28(4), 617-629.

Murugesan, S. (2007). Understanding Web 2.0. IT Professional, 9(4), 34-41.

Mustafa, A. K. A., \& Saat, M. M. (2013). Microfinance Institutions Performance Measurement: Introducing a New Performance Measurement Framework.Middle East Journal of Scientific Research, 15(11).

Nanayakkara, G., (2012). Measuring the Performance of Microfinancing Institutions. A New Approach. South. Asia Economic Journal, 13(1): 85-104

Nanayakkara, G., 2012. Measuring the Performance of Microfinancing Institutions. A New Approach. South. Asia Economic Journal, 13(1): 85-104

Nascimento, A. M., \& da Silveira, D. S. (2017). A systematic mapping study on using social media for business process improvement. Computers in Human Behaviour, 73, 670-675.

Nasir, S (2013) "Microfinance in India: Contemporary Issues and Challenges" Middle-East Journal of Scientific Research 15 (2): 191-199, 2013

Nisar, T. M., \& Whitehead, C. (2016). Brand interactions and social media: Enhancing user loyalty through social networking sites. Computers in Human Behavior, 62, 743-753.

Neti, S. (2011). Social media and its role in marketing. International Journal of Enterprise Computing and Business Systems, 1(2), 1-15.

Norell, N. (2001). How to reduce arrears in microfinance institutions. Journal of Microfinance/ESR Review, 3(1), 8.

Nugroho, L., Utami, W., Akbar, T. and Arafah, W. (2017). The Challenges of Microfinance Institutions in Empowering Micro and Small Entrepreneur to Implementing Green Activity. International Journal of Energy Economics and Policy, 7(3): 66-73.

Nyapati, K. (2011). Stakeholder Analysis of IT Applications for Microfinance. Advanced Technologies for Microfinance: Solutions and Challenges, 1.

Pakdel, N., \& Monroy, C. R. (2010, October). Microfinance in mena region: a partial success. In 4th International Conference on Industrial Engineering and Industrial Management (pp. 422-431).

Pateli, A. \& Mikalef, P. (2017). Configurations explaining the Impact of Social Media on Innovation Performance. In the Proceedings of the Pacific Asia Conference on Information Systems (PACIS2017), Langkawi, Malaysia, pp. 6-20.

Picoto, W., F. Be'langer, and A. Palma-dos-Reis. 2012. Leveraging on Mobile Business to Enhance Firm Performance: An Organizational Level Study. In the Proceedings of the European Conference of Information Systems, Barcelona, Spain, pp. 10-13. 
Pick, J. B., Gollakota, K., and Singh, M. (2014). Technology for development: Understanding influences on use of rural telecenters in India. Information Technology for Development, 20(4), 296-323.

Piller, F. T., Vossen, A., \& Ihl, C. (2012). From social media to social product development: The impact of social media on co-creation of innovation. Die Unternehmung, 65(1).

Powell, G., Groves, S., \&amp; Dimos, J. (2011). ROI of Social Media: How to improve the return on your social marketing investment. Singapore, John Wiley \& Sons.

Quadri, S. M. N., Singh, V. K., \& Iyengar, K. P. (2011). IT and MIS in Microfinance Institution Effectiveness and Sustainability Issues. Advanced Technologies for Microfinance, 33, 33-54.

Rimkuniene, D., \& Zinkeviciute, V. (2014). Social media in communication of temporary organisations: role, needs, strategic perspective. Journal of Business Economics and Management, 15(5), 899-914.

Rosenberg, R. ( 2009). Measuring Results of Microfinance Institutions. Minimum Indicators That Donors and Investors Should Track. CGAP. A Technical Guide.

Rozzani, N., Rahman, R. A., Mohamed, I. S., \& Yusuf, S. N. S. (2013). Applying Technology: Issues in Microfinance Operations. Middle-East Journal of Scientific Research, 17(3), 374-381

Ruisinger, D. (2007). Relations]: Online Relations. Leitfaden für moderne PR im Netz, SchäfferPoeschel Verlag, Stuttgart.

Sanfeliu, C. B., Royo, R. C., \& Clemente, I. M. (2013). Measuring performance of social and non-profit Microfinance Institutions (MFIs): An application of multicriterion methodology. Mathematical and Computer Modelling, 57(7), 1671-1678.

Saraf, N., Langdon, C. S. \& Gosain, S. (2007). IS application capabilities and relational value in interfirm partnerships. Information Systems Research, 18(3), 320-39.

Schaupp, L. C., \& Bélanger, F. (2013). The Value of Social Media for Small Businesses. Journal of Information Systems, 28(1), 187-207.

Serrano-Cinca, C., \& Gutiérrez-Nieto, B. (2014). Microfinance, the long tail and mission drift. International Business Review, 23(1), 181-194.

Shang, Y. (2014). Adoption of social media by SMTEs in China, Doctoral dissertation, University of Exeter-UK.

Siakas, K. V., Belidis, A., \& Siakas, E. (2014, June). Social media marketing for improved branding and valorisation in small family businesses. In International Conference on Contemporary Marketing Issues (ICCMI 2014)(pp. 18-20).

Statista (2018). Share of population in selected countries who are active WhatsApp users as of 3rd quarter 2017, e-source report, WhatsApp: usage penetration in selected countries 2017, The Statistics Portal (February, 2018). https://www.statista.com/statistics/291540/mobile-internetuser-whatsapp/ 
Tan, T., \& Phan, T. (2016). Social Media-Driven Credit Scoring: the Predictive Value of Social Structures. Research in progress.

Tan, T., Bhattacharya, P., \& Phan, T. (2016). Credit-worthiness Prediction in Microfinance using Mobile Data: A Spatio-network Approach. Research in progress.

Tang, S. Y., Painter, G. and Bhatt, N., (2002), "Microcredit Programs in the United States: The Challenges of Outreach and Sustainability", in Carr, J. and Tong, Z.Y. (Eds.), Replicating microfinance in the United States, Woodrow Wilson Center Press, Washington, D.C., pp. 191-221.

Tajvidi, R., \& Karami, A. (2017). The effect of social media on firm performance. Computers in Human Behavior. doi/10.1016/j.chb.2017.09.026

Todaro, M. P. \& Smith, S. C. (2009) Economic Development, Harlow, Pearson Education Limited.

Tang C., Mehl R. M., Eastlick M. A., He W. and Card A. N. (2016). 'A longitudinal exploration of the relations between electronicword-of-mouth indicators and firms' profitability: Findings from the banking industry'. International Journal of Information Management. 36, 1124-1132

Trainor, K. J. (2012). Relating social media technologies to performance: A capabilities-based perspective. Journal of Personal Selling and Sales Management, 3, 317-331.

Treem, J. W., \& Leonardi, P. M. (2013). Social media use in organizations: Exploring the affordances of visibility, editability, persistence, and association. Annals of the International Communication Association, 36(1), 143-189.

United Nations (2010) Establishment of the Global Financial Microfinance Framework, $14^{\text {th }}$ Meeting of the Intergovernmental Committee of Experts. 15-18 March, Kigali, Rwanda.

Wade, M., \& Hulland, J. (2004). Review: The resource-based view and information systems research: Review, extension, and suggestions for future research. MIS quarterly, 28(1), 107-142.

Wakuloba, R. (2006). Causes of Default in Government Micro-Credit Programmes. Journal Retrieved May, 13, 2013.

Waters, R. D. (2009). The use of social media by nonprofit organizations: An examination forms the diffusion of innovations perspective. In T. Dumova, \& R. Fiordo (Eds.), Handbook of research on social interaction technologies and collaboration software: Concepts and trends (pp. 473-485). Hershey, PA: IGI Publishing.

Wessel M., Thies F. and Benlian A. (2016). 'The emergence and effects of fake social information: Evidence from crowdfunding'. Decision Support Systems. 90, 75-85

Whiting, A., \& Williams, D. (2013). Why people use social media: A uses and gratifications approach. Qualitative Market Research: An International Journal, 16(4), 362-369.

Yaron, J. (1994). Successful rural finance institutions. Finance and Development, 31(1), 32.

Yaron, J., (1992). Successful rural finance institutions. World Bank-Discussion Papers

Zeiller, M., \& Schauer, B. (2011, September). Adoption, motivation and success factors of social media for team collaboration in SMEs. InProceedings of the 11th International Conference on Knowledge Management and Knowledge Technologies (p. 4). ACM. 
Zeller, M. and Meyer, R. L. (2002). The Triangle of Microfinance: Financial Sustainability, Outreach, and Impact. International Food Policy Research Institute (IFPRI). The Johns Hopkins University Press.

Zhu, K. (2004). The complementarity of information technology infrastructure and e-commerce capability: A resource-based assessment of their business value. J. Management Inform. Systems 21(1) 167-202.

Zhu, K., \& Kraemer, K. L. (2005). Post-adoption variations in usage and value of e-business by organizations: cross-country evidence from the retail industry. Information systems research, 16(1), 61-84.

Zhu, K., Kraemer, K. L., \& Xu, S. (2006). The process of innovation assimilation by firms in different countries: a technology diffusion perspective on e-business. Management science, 52(10), 15571576.

Appendix 1: Questionnaire Items and their Sources

\begin{tabular}{|c|c|c|}
\hline Construct & Item & Source \\
\hline \multirow{6}{*}{$\begin{array}{l}\text { Social Media Types } \\
\text { (SMT) }\end{array}$} & Picture and video broadcasting websites. & \multirow{6}{*}{ Shang (2014) } \\
\hline & Social networking website. & \\
\hline & Product review system website. & \\
\hline & Microblogging & \\
\hline & $\mathrm{B} \operatorname{logs}$ & \\
\hline & Document management. & \\
\hline \multirow{4}{*}{ Efficiency (EIO) } & Internal operations more efficient. & \multirow{4}{*}{$\begin{array}{l}\text { Zhu and Kraemer } \\
\text { (2005); } \\
\text { Picoto et al., (2012) }\end{array}$} \\
\hline & Improved decision making. & \\
\hline & Reduce administration workload. & \\
\hline & Better information quality. & \\
\hline \multirow{5}{*}{$\begin{array}{l}\text { Communication } \\
\quad(\mathrm{COM})\end{array}$} & Facilitate communication among employees. & \multirow{5}{*}{$\begin{array}{c}\text { Andriole (2010); } \\
\text { Picoto } \text { et al., (2012); } \\
\text { Schaupp and Belanger } \\
\text { (2013); } \\
\text { Lee (2015) }\end{array}$} \\
\hline & Facilitate communication with customers. & \\
\hline & Ability to audit communications streams. & \\
\hline & Improved communication performance. & \\
\hline & Ability to reach more people faster. & \\
\hline \multirow{4}{*}{ Staff Productivity (SP) } & Staff productivity increased & \multirow{4}{*}{$\begin{array}{c}\text { Picoto et al., (2012); } \\
\text { Schaupp and Belanger } \\
\text { (2013) }\end{array}$} \\
\hline & Increased staff motivation and satisfaction & \\
\hline & Improved employee effectiveness & \\
\hline & Easier for the staff to do their job & \\
\hline \multirow{5}{*}{$\begin{array}{l}\text { Financial Sustainability } \\
\text { (FS) }\end{array}$} & Increased profitability. & \multirow{5}{*}{$\begin{array}{c}\text { Zhu et al., (2006b); } \\
\text { Picoto et al., (2012); } \\
\text { Schaupp and Belanger } \\
\text { (2013) }\end{array}$} \\
\hline & Operational costs decreased. & \\
\hline & Reduced marketing costs. & \\
\hline & Inventory costs decreased. & \\
\hline & Total cost decreased. & \\
\hline \multirow{4}{*}{ Portfolio Quality (PQ) } & Improved loan repayment. & \multirow{4}{*}{$\begin{array}{c}\text { Rosenberg (2009); } \\
\text { Nanayakkara (2012) }\end{array}$} \\
\hline & Decreased portfolio at risk. & \\
\hline & Decreased defaults rate. & \\
\hline & Decreased arrears rate. & \\
\hline \multirow{2}{*}{$\begin{array}{c}\text { Outreach } \\
\text { (BDO) }\end{array}$} & Outreach increased. & \multirow{2}{*}{ Nanayakkara (2012); } \\
\hline & Outreach area widened. & \\
\hline
\end{tabular}




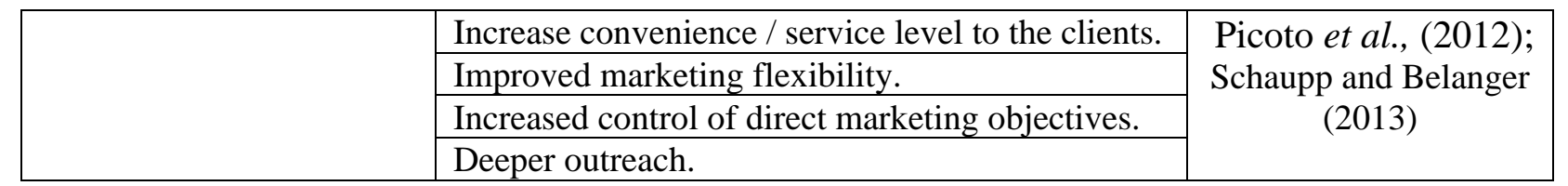

